\title{
Predicting Factors Influencing Online Purchase Behavior among Indian Youth
}

\author{
Sanjeev K. Sharma, Pooja Chopra*
}

\begin{abstract}
To keep pace with the growing magnitude of the online retail platform in the Indian subcontinent, it has become crucial for e- retailers and marketers to decipher the key antecedents of customers' purchase intention amongst the young Indian online customer. This study attempts to frame a conceptual model for finding the key determinants for online purchase intentions based on the data collected from 238 participants using the structured questionnaire method. Structured Equation Model was used on data collected to test hypothesizes of study. The study highlights that eWOM was the major contributing factor for Indian youth while shopping online This paper contributes to highlighting the importance of these factors and help e-marketers develop more customer specific marketing strategies to enhance the purchase intentions.
\end{abstract}

Keywords: Marketing Strategies, Online Customer, Purchase Intentions.

\section{INTRODUCTION}

India is swiftly bracing itself to usher the new era of digital revolution. Today, the Internet has enlightened the glimmer of hope amongst people in innumerable ways like connecting with near and dear ones, creating awareness on critical issues, making electronic payments when needed and what not. The prime constituent that drives the growth of internet users is easy availability of smart phones and economic mobile data plans[1]. India will have a lion's share of 500 million internet users base by 2018 [2]. The upsurge in online shopping trend is not just due to India's booming internet penetration, but also due to massive development in supporting ecosystem along with relaxed government regulations [3]. Indian consumer's attitude for online shopping has gone through a massive transformation. Government support, venture capitalists, angel investors, logistic providers, payment infrastructure providers, who were earlier limiting themselves to the sidelines, are now keenly focused on upgrading India's e-Commerce market [4]. Burgeoning internet users' market, rapid technology adoption, growing affinity for online payments, promising demographic dividend, has led to the magnificent growth tale of e-Commerce in our country [5]. Internet users' database in India is projected to stretch from 429.23 million in 2017 to 829 million by 2020 [6]. The landmark initiative "Digital India" is a proactive stance towards Internet penetration among masses and for transforming India into a digitally empowered society and has made a buzz across the globe [7]. The homegrown players such as Flipkart and Snapdeal have swayed the Indian market by leaps and bounds. Moreover, with the inroads made by the international e-commerce behemoths such as Amazon and Alibaba, having international expertise, rich domain knowledge, loyal customer base gives them a competitive advantage globally [8] The Indian e-commerce market is expected to take a giant leap from US\$ 38.5 billion in 2017 to US\$ 200 billion by 2026 [6].

\section{INDIAN ONLINE SHOPPING PLAYERS}

E-commerce giants such as Amazon and Alibaba have made inroads into the Indian territory thereby intensifying the competition. Both these players have colossal power in terms of capital, robust R\& D team, strong domain knowledge and the endurance and persistence to propel the Indian e-Commerce market to new avenues [9]. Their excellent domain expertise along with rich operating experience from their international presence has helped them in out witting the competition. Moreover, these players have been in the markets from a fairly longer span of time and have seen the e-Commerce market evolving into a big ocean of opportunities. Additionally, they also have to keep an eye on the various challenges, strategies, and issues that are crucial to be addressed for a smooth sailing in Indian market [8]. On the flip, local players of Indian market have to be quite vigilant in expanding their seller base, innovating on multiple customer touch points so as to provide a fabulous and efficient transmission of goods and services in order to give a tough fight to their international competitors [2]. In 2015, the Indian e-commerce landscape underwent a paradigm shift with big Indian business houses like Reliance, Tatas and Birlas venturing with their own e-commerce platform by investing $\$ 2$ to have an enduring foothold in the Indian e-commerce market [10].

\section{OBJECTIVE OF THE STUDY}

Presuming the objectives of the study was to identify the key factors affecting young consumers online purchase intentions, a theoretical framework was developed to analyze the antecedents of online purchase intentions in India. Objective was to identify the key fcators that influence Indian consumers' online purchase intentions and to recognize the importance of these each factor that affect young consumers' online purchase intentions. 


\section{REVIEW OF LITERATURE}

In this section, extensive review on existing literature regarding the salient variables of the study namely consumers' online purchase intention, followed by the additional constructs like e-word of mouth, return policy, perceived risk, prior shopping experience has been done so as to further facilitate in framing research hypotheses.

\section{A. Perceived Risk}

Risk plays a major role in describing consumer's search behavior and purchase decision making process [11]. Traditionally risk is envisioned as "the subjective probability" of the one's belief that their personal data might be maneuvered by the service provider leading to unexpected consequences [12]. Risk is basically anxiety, insecurity, and vulnerability about the decision while purchasing products online [13]. Several authors have pinpointed in their studies that in online shopping sites, the risk is much more in comparison to brick and mortar model shopping formats [14]. There are several instances where consumers undergo abashment because of impersonal interaction, dearth of touch and feel effects while doing online purchases [15-16]. Customers often have apprehensions regarding e-vendors' being opportunistic [17] as they sometimes fail to supply the right product within the promised time frame [18]. Consumers undergo financial frauds [11], deal with leaked personal and confidential information and becoming victim of the mendacious advertisements on the shopping websites by e-vendors. Product's performance risk is linked with the hazards associated with the non-functionality of the product [19-20] whereas financial risk is linked with unreliability conjoined with the monetary loss due to the security issue while making electronic payments or even product/service failure [21]. However, time risk in linked with the unnecessary difficulties or hindrances that a consumer experience while surfing website, placing orders, or waiting for the product delivery [22]. Due to these risks consumers often show resistance to do online purchasing [23]. The lack of perceived trust because of multi facet risks has been identified as one of the most vital deterrent that hinders the penetration of e-shopping for enhancing the frequency of purchase intentions [24].

\section{B. Return Policy}

Appropriately framed return policy fosters trust among the shoppers as it mitigates the perceived risk associated with the purchase transaction [24], signals quality and credibility of the product [25]. This also result in positive long term relational cues, avoiding pessimistic thoughts while shopping online [26] and mitigating any apprehensions that clouds customers' price decision. The willingness to purchase online increases many folds due to liberal returns policy as it empowers customers in establishing strong reliability [27] in the firm and in the brand. Return policies are framed keeping in mind the reverse logistics mechanism along with retailer's commitment for efficient $\&$ effective service recovery process at least loss [28]. This aids in lower customer turnover ratio and increasing the total revenue for the organization [29]. Return policies are chalked out to minimize customer dissatisfaction due product selection errors or wrong processing by backend and to ensure faster processing of returns, refunds and replacement of products within estimated time frame [30]. Customer friendly return policies aid in lowering dissonance if damaged or defective products are received [31]. Liberal returns policy is basically associated with service failure and facilitates smooth service recovery process and results in customer retention, loyalty which ultimately enhances long-term sales. However, a research done by [32] highlights that buyers who have encountered a retune experience with an online site, purchases more products and order more frequently from the same site compared to ones who have no experience of returning goods. Additionally, return policies are chalked out to facilitate consumers' propensity to spend and purchase more often in the future [33]. Consumers link retailer's return shipping insurance as a reliable cue for commodity quality and credibility, which strengthens the propensity to purchase from the same retailer in future [34].

\section{Electronic Word of Mouth}

In the recent times, electronic word of mouth [eWOM] has become more prominent and credible factor affecting consumer's perceptions [35-36] than any other marketing communication channels [37-38] Although the power of positive WOM has a considerable influence on consumer decision making process [39] but, previous research has also proved that negative WOM can also be influential in purchase decision process [40] as dissatisfied customers tend to report their experience more than those who are satisfied ones [41]. Previous studies have substantiated the fact that consumers perceive WOM as more trustworthy, convincing, and credible than traditional sources. eWOM communications exhibit exceptional reach and speed of diffusion that empowers consumers to connect, and transform consumers from complacent observers to active participants [42]. Seekers of testimonials from consumers are interested in hedging risk and to have an easy accessibility of relevant information prior to purchase decisions leads to reduced post purchase dissonance [43]. Numerous studies have linked the influence of eWOM with brand image [44], trust [45] product attributes [46], consumer decision-making [47] and e-commerce sales [48]. Thus, we can say that eWOM fuels consumers online purchase behavior.

\section{Prior Shopping Experience}

It can be premised that with the rapidly technological changes people's preferences are slowly inching towards the digital shopping [49] and enhanced service delivery experience [50]. Therefore, online shopping consumers rely extensively on shopping experience. Customers often appraise their online purchase experiences by scrutinizing their observation regarding merchandise information, delivery terms, payment mechanism, services provided, risk involved, security issues, privacy concerns, personalization \& customization of offerings, visual stimuli along with ease of navigation [51]. [52] opined that initially a consumer goes for small purchases which stimulates confidence and pushes him for frequent buying regime.

If prior online purchase experiences are fair, it surely signals customers' continuance to shop online in the future as well [53]. Unfortunately, if the past

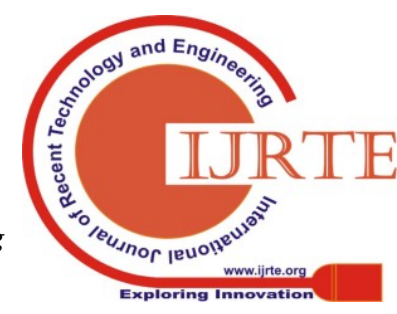


experience is negative, then consumers will be apprehensive in doing online shopping in future. Therefore, previous purchase experience would affect the consumers' willingness to either visit or purchase from the same website. Another relevant aspect of behavioral modeling is purchase recency [54] as it signals higher purchase likelihood in future [55].

\section{E. Online Purchase Intentions}

These days. internet along with rapid development in technology has transformed the way people shop. This global market place operates $24 \times 7$ round the year, neutralizing time and location constraints [56]. Additionally, this has led to the surfacing of a new consumer segment named 'online Consumer'. These consumers exhibit different purchasing patterns in comparison to traditional 'brick and mortar' customers. Consumers' online purchase intention mirrors their preference to buy merchandises through an e-commerce platform [57] Theory of planned behavior too explains the rationale behind consumers' behavioral intentions [58-59]. Online purchase intention is an appropriate way to assess online consumer behavior[60]. Purchase intention rests upon numerous factors as it involves vigorous information sharing and processing [61]. Therefore, to stimulate online purchase intention among consumers, e- retailers need to focus on key factors that could multiply their chances of purchasing online and provide customers with a pleasing experience.

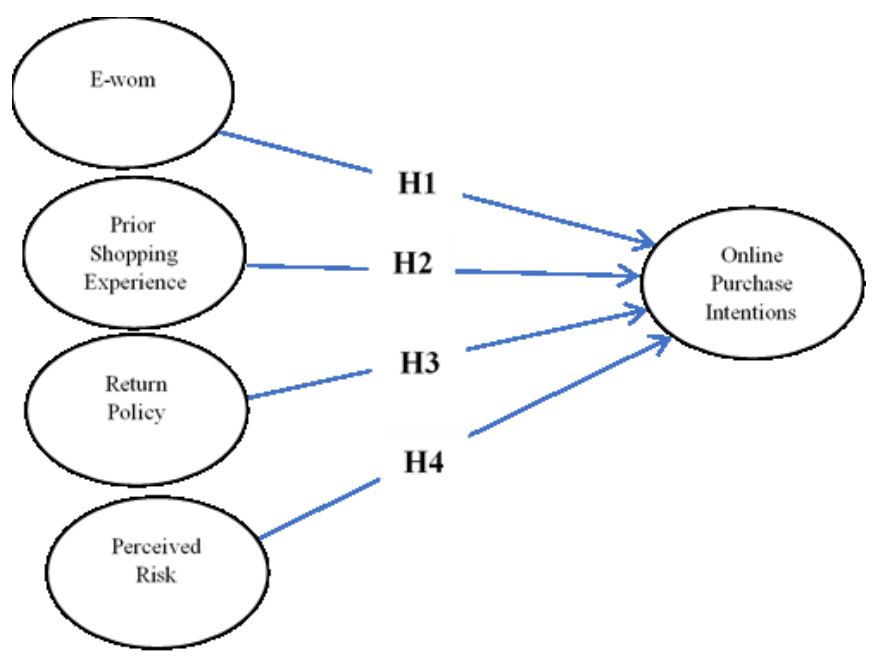

\section{RESEARCH METHODOLGY}

To ascertain the sound indicators of consumers' online purchase intentions behavior, a self-administered questionnaire was framed based upon available existing literature. The questionnaire consisted of two parts. First part has the questionnaire pertains to the demographic profile like gender, age, marital status, household income, educational qualification of the potential respondents. Second part had the questions pertaining to dependent variables [eWOM, return policy, perceived risk, and prior shopping experience] and the independent variable [purchase intentions] that were to be explored in the study. Table 3 highlights the scale items used in the study which has been adopted from various research papers. The scale items were presented on a five-point Likert scale, varying from 1 [strongly disagree] to 5 [strongly agree] as scaling allows correct assessment of the intensity of respondents' responses [62]. The questionnaire was reviewed by two marketing experts for incorporating their valuable insights. Pre-testing was done on a random sample of 100 people who were aged above 21 years and have shopped online in the last 6 months. Responses from these consumers were utilized to modify the wordings to make it apt for the respondents to understand and provide a fair response. The reliability and validity of our questionnaire [62] was also thoroughly checked during the pretesting process.

\section{A. Sample size and data collection}

A strong and reliable internet connection a strong reliable Internet connection is a necessary prerequisite for e-commerce.[63]. Indian online shopping is primarily dominated by the large coherent of youngsters, who are heavy users of internet [3]. Since, Chandigarh and its periphery cities is a hub of management schools [64] that provide continuous internet access to its students, so it decided to make them a part of our target sample for our study. The online survey method was used so that maximum target population could be reached, in most cost-effective manner in the least possible time. In total, 250 postgraduate MBA students from two renowned management schools participated in our research. An e-questionnaire was sent via email to the students. Out of which 206 respondents have reverted back who have done online shopping.

\section{INTERPRETATION AND CONCLUSION}

This section deals with the interpretation along with discussion of the key findings

\section{A. Respondents demographic profile regarding online purchase behavior}

Sample results shows that $39.89 \%$ of the total respondents are male while $60.11 \%$ are females. $83.76 \%$ of the respondents had the experience of purchasing products and services though online mode. Nearly half of the respondents [54.79\%] use plastic money as a primary mode of payment while online purchasing the products

\section{B. Measurement Model}

As our study entails using an already developed measurement scales [Table 3] in an entirely new domain of study, and to identify the basic structure of the underlying variables in the proposed research model. EFA was conducted using principal axis extraction method. Varimax rotation [65] was preferred as it provides an easy interpretability of factor matrix [66]. This resulted in retaining 20 items out of 24 items with factor loadings more than 0.50 and rest were deleted. The final factor analysis result had 20 items measuring 5 factors, which resulted in 65.92 percent of the total variance which is above the minimum threshold level of $60 \%$ [67]

The Kaiser-Meyer-Olkin measure for measuring sample adequacy was found to be 0.776 . Each factor had minimum three items based on the factor loadings $<.5$ [ 68] and Eigen values greater than 1 . Table 1 depicts the extracted factors and variable under each factor using rotated component matrix.

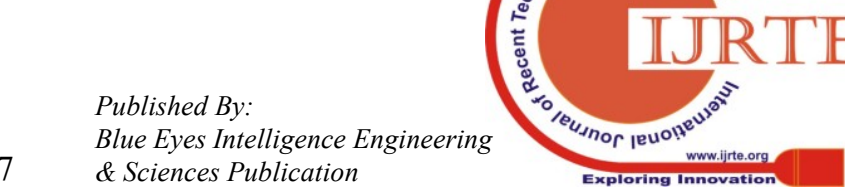


Predicting Factors Influencing Online Purchase Behavior among Indian Youth

\begin{tabular}{|c|c|c|}
\hline \multirow{2}{*}{ S. No. } & \multicolumn{2}{|l|}{ Table 1 : Factor analysis } \\
\hline & Statements & $\begin{array}{c}\text { Factor } \\
\text { loadings }\end{array}$ \\
\hline \multicolumn{3}{|l|}{ Factor 1} \\
\hline 1 & $\begin{array}{l}\text { I recommended this company for online } \\
\text { purchase }\end{array}$ & .818 \\
\hline 2 & I speak of this company's good sides & .785 \\
\hline 3 & $\begin{array}{l}\text { I am proud to say to others that I buy } \\
\text { products from company's website. }\end{array}$ & .712 \\
\hline 4 & $\begin{array}{l}\text { I strongly recommend people buy products } \\
\text { online from this website }\end{array}$ & .684 \\
\hline 5 & $\begin{array}{l}\text { I mostly say positive things to others about } \\
\text { this online company }\end{array}$ & .635 \\
\hline \multicolumn{3}{|c|}{ (15) } \\
\hline 1 & $\begin{array}{l}\text { I feel comfortable using the online shopping } \\
\text { web sites }\end{array}$ & .677 \\
\hline 2 & $\begin{array}{l}\text { I am experienced with the use of the online } \\
\text { shopping web sites }\end{array}$ & .655 \\
\hline 3 & $\begin{array}{l}\text { I feel competent of using the online } \\
\text { shopping web sites }\end{array}$ & .604 \\
\hline \multicolumn{3}{|l|}{ Factor 3} \\
\hline 1 & $\begin{array}{l}\text { I am willing to buy products from this } \\
\text { website. }\end{array}$ & .615 \\
\hline 2 & $\begin{array}{l}\text { The likelihood of me purchasing products } \\
\text { from this website is high. }\end{array}$ & .539 \\
\hline 3 & $\begin{array}{l}\text { I intend to purchase through the website in } \\
\text { the future. }\end{array}$ & .777 \\
\hline 4 & $\begin{array}{l}\text { I consider the website my first choice when } \\
\text { buying products from online retailers }\end{array}$ & .689 \\
\hline \multicolumn{3}{|l|}{ Factor 4} \\
\hline 1 & Risk of making a poor purchasing decision & .841 \\
\hline 2 & Inability to inspect the product & .510 \\
\hline 3 & Risk of compromising personal information & .568 \\
\hline \multicolumn{3}{|l|}{ Factor 5} \\
\hline 1 & $\begin{array}{l}\text { The online store identifies return using } \\
\text { wider criteria. }\end{array}$ & .824 \\
\hline 2 & The online store promises a large return. & .787 \\
\hline \multirow[t]{2}{*}{3} & $\begin{array}{l}\text { The online store identifies return using } \\
\text { wider criteria. }\end{array}$ & .640 \\
\hline & $\begin{array}{l}\text { Kaiser-Meyer-Olkin Measure of } \\
\text { Sampling Adequacy(KMO) }\end{array}$ & .766 \\
\hline \multirow{4}{*}{$\begin{array}{l}\text { Bartlett's Test } \\
\text { of Sphericity }\end{array}$} & Approx. Chi Square & 2134.178 \\
\hline & Df & 190 \\
\hline & Sig. & .000 \\
\hline & Approx. Chi Square & 2134.178 \\
\hline
\end{tabular}

Convergent validity was also established as the loading of each of the individual items in a construct is higher than 0.5 [67]. On the basis of the explored factors the following hypotheses were framed:

H1: eWOM is positively associated with online purchase intentions.

H2: Prior shopping experience is positively associated with online purchase intentions.

H3: Return policy are positively associated with online purchase intentions.

H4: Perceived risk has a negative association with online purchase intentions.

Data fitting of the model

Good Fit [value should be less than 3] Good Fit, should be less than 0.08

Not a Good Fit [should be greater than 0.90

Not a Good Fit [should be greater than 0.90 Good Fit [should be greater than 0.90 ] Good Fit [should be greater than 0.90$]$ Good Fit [should be greater than 0.90] Good Fit [should be greater than 0.90] Good Fit [should be greater than 0.90] Good Fit [should be less than 0.08 ]

Square Error

\section{Structural model estimation and Hypothesis and Path Testing}

For hypothesis testing and to ascertain if the theoretical relationships framed during the conceptualization phase are endorsed by the data also [75], Hypothesis path testing was done 


\section{CONCLUSION AND RECOMMENDATION}

The results of our analysis justify the acceptance of all proposed hypotheses along with validating the research model. This will provide valuable insights for fostering online purchase intentions amongst young customers. These findings present the prominent role of an eWOM in understanding people's perception regarding the product's pros, cons, price, utility and its worth. Due to the time constraint, consumers are hesitant to make frequent visits to the market. Hence customers treat eWOM can be an ideal platform to collect product/ service information through internet. Additionally, consumers also perceive that online information is unbiased. Therefore, individuals prefer to read eWOM comments before framing their purchase decision [76]. When eWOM readers gain substantiated and convincing information as they believe that eWOM provides factual information regarding the experiences concerning the particular products [77]. This result is consistent with the literature $[78,36]$. Our study also points out that perceived risk is the key inhibitor in consumer's adoption of online shopping. This is consistent with the previous researchers $[79,80,81]$. Thus, online retailers ought to judiciously chalk out blue print of risk-reducing strategies so as to curtail perceived risk in shopping online and maximize online purchase intentions [82]. Online retailers ought to highlight the privacy policies along with their online security mechanism on their website. They should invest in superior encryption technology as a means for security measure. To minimize consumers' apprehensions regarding 'feel and touch' aspect of the product in an online shopping purchase, comprehensive product information should be provided on the web pages, so as to make it easy for the consumers to shop without any suspicion in their mind. Considering the importance of prior shopping experience, this study highlights the understanding the customer experience that adds to the reasoning that will help in predicting the future buying behavior. This is in consonance with the research findings of [83] online marketers need to address the issues of low-quality product, post-purchase dissonance, unsafe payment mechanism and fake goods in timely and just manner. This will not only enhance the trust among the shoppers but also stimulate in making online shopping a pleasant experience [84]. A favorable previous purchase experience correlates positively with consumers' likelihood to repeat online shopping. This finding is consonance with the traditional attitude-behavior models [85-86]. Marketers should do correct profiling of the customers along with providing value added services, as they have a strong and direct effect in lowering the information search cost. They can effectively retain the consumers. Our study too validates this notion that offering free returns is an incentive to buy. Marketers should understand and formulate customer friendly simple, transparent, and generous return policy to earn customer loyalty.

E-retailers need to formulate easy to understand return policy. Responding and acknowledging promptly to customers' queries, requests and grievances will not only make customers happy but also win their share of wallet in the times to come. 


\section{LIMITATIONS}

Our research has provided relevant and interesting insights towards understanding of young Indian consumers' online purchase consumers' intentions. Still there are few, limitations associated with our study. However, studying the antecedents of online consumer purchase behavior has a broad spectrum. Our research was confined only to a modest geographical dimension. It is noteworthy that the results and analyses of this study were limited to the convenience sample of college-aged students which may not be truly representative for the entire population. A bigger and more representative sample comprising of respondents from other geographical regions would have been more appropriate. Besides this, online purchase intentions could be further explored by including new constructs like trust, website quality, product categorization and frequency of buying can provide promising direction.

\section{REFERENCES}

1. Simon Kemp, Digital in 2018: World's Internet users pas the 4 billion Mark

https://wearesocial.com/blog/2018/01/global-digital-report-2018

2. IAMAI and Kantar IMRB Report, mobile internet report 2017. https:/cms.iamai.in/Content/ResearchPapers/2b08cce4-e571-4cfe-9f 8b-86435a12ed17.pdf

3. GSM Association, A new regulatory framework for the digital ecosystem, 2016.

https://www.gsma.com/publicpolicy/wpcontent/uploads/2016/09/GS MA2016 Report_NewRegulatoryFrameworkForTheDigitalEcosyste m English.pdfik

4. Ernst And Young Report, Rebirth of e-commerce of India (2013). https://www.ey.com/Publication/vwLUAssets/Rebirth of e-Commer ce in_India/\$FILE/EY_RE-BIRTH_OF_ECOMMERCE.pdf

5. $\mathrm{KPMG}$ FICCI Report The-Future-now-streaming, 2016 https://home.kpmg/content/dam/kpmg/pdf/2016/04/The-Future-nowstreaming.pdf

6. IBEF, E-Commerce Report, 2018 https://www.ibef.org/download/Ecommerce-Report-Jan-2018.pdf

7. IBM Kalaari Report. Imagining Trillion Dollar Digital India, 2018. https://kstart.in/wp-content/uploads/2018/04/Imagining-Trillion-Doll ar-Digital-India-IBM-Kalaari-Research-Report-April-2018.pdf.

8. PWC Report 2015. e-commerce in India Accelerating Growth. https://www.pwc.in/assets/pdfs/publications/2015/ecommerce-in-indi a-accelerating-growth.pdf

9. R. Sachitanand and G Seetharaman. ET Bureau| Updated: May 20 , 2018 Amazon vs Google: A race to capture India's consumer space https://economictimes.indiatimes.com/tech/internet/amazon-vs -google-a-battle-to-capture-the-indian-ecommerce-space/articleshow/ 64238190.cms

10. R.Bailay , C. Chakravarty Reliance Industries to enroll 1.5 lakh vendors for its ecommerce venture. 2015. https://economictimes.indiatimes.com/industry/services/retail/relianc e-industries-to-enroll-1-5-lakh-vendors-for-its-ecommerce-venture/art icleshow/49445234.cms

11. I. B. Hong, "Understanding the consumer's online merchant selection process: The roles of product involvement, perceived risk, and trust expectation" International Journal of Information Management, 35(3), 322-336, 2015. https://doi.org/10.1016/j.ijinfomgt.2015.01.003

12. M. S Featherman,.P.A. Pavlou, "Predicting e-services adoption: a perceived risk facets perspective" International journal of human-computer $\quad$ studies, 59(4), 451-474, 2003. https://doi.org/10.1016/S1071-5819(03)00111-3

13. J.M. Alcántara-Pilar, S. Del Barrio-García,L. Porcu, E Crespo-Almendros, " Motivational duality in online consumer behaviour: Website usability and flow state as moderating factors" International Journal of Business and Economics, 14(1), 79-104, 2015

14. K.S.Lee, S.J. Tan, "E-tailing versus physical retailing: a theoretical model and empirical test of consumer choice", Journal of Business Research, 56(11), 877-85 https://doi.org/10.1016/S0148-2963(01)00274-0
15. C.H. Chen, G.S. Mort, "Consumers' technology adoption behaviour: an alternative model. The Marketing Review, 7(4), 355-368,2007. https://doi.org/10.1362/146934707X251119

16. D.Gefen, D, P.A. Pavlou, "The boundaries of trust and risk: The quadratic moderating role of institutional structures" Information Systems $\quad$ Research, 23(3-part-2), 940-959, 2012 https://doi.org/10.1287/isre.1110.0395

17. S.San-Martín, C.Camarero, "How Can E-Vendors Create Trust in B2C and C2C Contexts?. In Mobile Commerce: Concepts, Methodologies, Tools, and Applications" 1390-1412. IGI Global, 2018. https://doi.org/10.4018/978-1-5225-2599-8.ch066

18. Q. Yang, C. Pang, L. Liu, D.C. Yen, J.M. Tarn, "Exploring consumer perceived risk and trust for online payments: An empirical study in China's younger generation". Computers in Human Behavior, 50, 9-24, 2015.https://doi.org/10.1016/j.chb.2015.03.058.

19. H.R.Marriott, D.W. Michael, "Exploring consumers perceived risk and trust for mobile shopping: A theoretical framework and empirica study." Journal of Retailing and Consumer Services 42, 133-146, 2018. https://doi.org/10.1016/j.jretconser.2018.01.017 19

20. N.M.Suki, N.M. Suki, "Modeling the determinants of consumers' attitudes toward online group buying: Do risks and trusts matters?.' Journal of Retailing and Consumer Services, 36, 180-188, 2017.https://doi.org/10.1016/j.jretconser.2017.02.002.

21. D.Biswas, A.Biswas, "The diagnostic role of signals in the context of perceived risks in online shopping: do signals matter more on the web?", Journal of Interactive Marketing, 18 (3),30-45. 2004.https://doi.org/10.1002/dir.20010.

22. J.Mou, D.H. Shin, J.F. Cohen, "Trust and risk in consumer acceptance of e-services. Electronic Commerce Research, 17(2), 255-288, 2014. https://doi.org/10.1007/s10660-015-9205-4.

23. N.Arora, M. Rahul, "The role of perceived risk in influencing online shopping attitude among women in India." International Journal of Public Sector Performance Management, 4(1), 98-113, 2018.https://doi.org/10.1504/IJPSPM.2018.088697.

24. P.Oghazi, S.Karlsson, D.Hellström, K. Hjort, “ Online purchase return policy leniency and purchase decision: Mediating role of consumer trust." Journal of Retailing and Consumer Services, 41, 190-20,.2018. https://doi.org/10.1016/j.jretconser.2017.12.007.

25. Z.Pei,A. Paswan, R. Yan, "E-tailer' s return policy, consumer' s perception of return policy fairness and purchase intention" Journal of Retailing and Consumer Services, 21(3), 249-257, 2014 https://doi.org/10.1016/j.jretconser.2014.01.004

26. N. Janakiraman, H.A. Syrdal, R. Freling, "The effect of return policy leniency on consumer purchase and return decisions: a meta-analytic

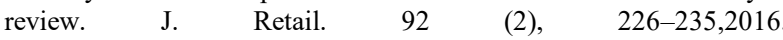
https://doi.org/10.1016/j.jretai.2015.11.002

27. A. B. Bower, J.G. Maxham III, "Return shipping policies of online retailers: normative assumptions and the long-term consequences of fee and free returns.”Journal of Marketing, 76(5), 110-124, 2012 https://doi.org/10.1509/jm.10.0419

28. N.Y.Jung, Y.K. Seock, "Effect of service recovery on customers' perceived justice, satisfaction, and word-of-mouth intentions on online shopping websites. Journal of Retailing and Consumer Services, 37, 23-30, 2017.https://doi.org/10.1016/j.jretconser.2017.01.012

29. J.A.Petersen, V. Kumar, "Are product returns a necessary evil? Antecedents and consequences" Journal of Marketing, 73(3), 35-51,2009. https://doi.org/10.1509/jmkg.73.3.035

30. S.Rao, K.B. Lee, K. B., B.Connelly, D.Iyengar, "Return time leniency in online retail: a signaling theory perspective on buying outcomes. Decision Sciences, 49(2), 275-305, 2018 https://doi.org/10.1111/deci.1227

31. S.E. Griffis, S. Rao, T.J. Goldsby, T. T. Niranjan, "The customer consequences of returns in online retailing: An empirical analysis" Journal of Operations Management, 30(4), 282-294,2012. https://doi.org/10.1016/j.jom.2012.02.002

32. G. Walsh, D, Brylla, "Do product returns hurt relational outcomes? some evidence from online retailing" Electronic Markets, 27(4), 329-339, 2017. https://doi.org/10.1007/s12525-016-0240-3

33. J.Zhang, H. Li, R. Yan, C. Johnston, “ Examining the signaling effect of e-tailers' return policies. Journal of Computer Information Systems, 57(3), 191-200., https://doi.org/10.1080/08874417.2016.1183989

34. S. Teng, K.W. Khong, A.Y.L. Chong, B. Lin, "Examining the impacts of electronic word-of-mouth message on consumers' attitude. Journal of Computer Information Systems, 57(3), 238-251, 2017. 
https://doi.org/10.1080/08874417.2016.1184012

35. M. Lee ,S. Rodgers, M. Kim, 'Effects of valence and extremity of eWOM on attitude toward the brand and website. Journal of Current Issues \& Research in Advertising, 31(2), 1-11, 2009. https://doi.org/10.1080/10641734.2009.10505262

36. L.V. Casalo, C. Flavian, M. Guinaliu, Y. Ekinci, "Do online hotel rating schemes influence booking behaviors?", International Journal of Hospitality Management, 49,28-36, 2015. https://doi.org/10.1016/j.ijhm.2015.05.005

37. B. Coker, A. Nagpal, "Building-up versus paring-down: consumer responses to recommendations when customizing", Journal of Retailing, $\quad 89 \quad$ (2), https://doi.org/10.1016/j.jretai.2012.11.002

38. Y.Wang, C.Yu, "Social interaction-based consumer decision-making model in social commerce: The role of word of mouth and observational learning. International Journal of Information Management, 37(3), 179-189, https://doi.org/10.1016/j.ijinfomgt.2015.11.005

39. H.Luo, W. Huang, C, Chen, K. Xie, Y. Fan, "An Empirical Study on the Impact of Negative Online Word-of-Mouth on Consumer's Purchase Intention. In 2018 15th International Conference on Service Systems and Service Management (ICSSSM) (pp. 1-6). IEEE.2018. https://doi.org/10.1109/icsssm.2018.8465093

40. N. Hill, J. Alexander, The handbook of customer satisfaction and loyalty measurement. Routledge, 2017

41. S.C. Chu, Y. Kim. "Determinants of Consumer Engagement in Electronic Word-of-Mouth (eWOM) in Social Networking Sites." International Journal of Advertising 30 (1), 47-75, 2011. https://doi.org/10.2501/IJA-30-1-047-075

42. I. Erkan, C. Evans, "Social media or shopping websites? The influence of eWOM on consumers' online purchase intentions" Journal of Marketing Communications, 24(6), 617-632, 2018. https://doi.org/10.1080/13527266.2016.1184706

43. A. Krishnamurthy, S.R. Kumar, "Electronic word-of-mouth and the brand image: Exploring the moderating role of involvement through a consumer expectations lens" Journal of Retailing and Consumer Services, 43 , 149-156, https://doi.org/10.1016/j.jretconser.2018.03.010

44. Z.A. Bulut, A.N. Karabulut, "Examining the role of two aspects of eWOM in online repurchase intention: An integrated trust-loyalty perspective" Journal of Consumer Behaviour, 17(4), 407-417,2018. https://doi.org/10.1002/cb.1721

45. H.J. Jeong, D.M. Koo, "Combined effects of valence and attributes of e-WOM on consumer judgment for message and product: The moderating effect of brand community type. Internet Research, 25(1), 2-29, 2015. https://doi.org/10.1108/IntR-09-2013-0199

46. G. Moran, L. Muzellec, E. Nolan, "Consumer moments of truth in the digital context: How "search" and "e-word of mouth" can fuel consumer decision making" Journal of Advertising Research, 54(2), 200-204., 2014. https://doi.org/10.2501/JAR-54-2-200-204

47. J. Hernández-Méndez, L. Francisco Muñoz, F. Juan Sánchez, "The influence of e-word-of-mouth on travel decision-making: consumer profiles." Current issues in tourism 18(11), 1001-1021, 2015. https://doi.org/10.1080/13683500.2013.802764

48. E. Pantano, C.V. Priporas, "The effect of mobile retailing on consumers' purchasing experiences: A dynamic perspective" Computers in Human Behavior,61, 548e555, 2016. https://doi.org/10.1016/j.chb.2016.03.071

49. G. McLean,A. Wilson, "Evolving the online customer experience... is there a role for online customer support? Computers in Human Behavior, $60,602 \mathrm{e} 610,2016$. https://doi.org/10.1016/j.chb.2016.02.084

50. B. Rishi, A.H.M.A,Khasawneh, "Determinants of online purchase intention: a study of Emirati consumers. International Journal of Islamic Marketing and Branding, 2(3), 200-214, 2017. https://doi.org/10.1504/IJIMB.2017.087967

51. V. Seckler, "Survey says web apparel buys doubled', Women Wear Daily, 12[2], 2000.

52. E.E.Izogo, \& C. Jayawardhena, " Online shopping experience in an emerging e-retailing market. Journal of Research in Interactive Marketing,

193-214,2018. https://doi.org/10.1108/JRIM-02-2017-0015

$12(2)$

53. P.K. Kannan, H.A. Li, "Digital marketing: a framework, review and research agenda". International Journal of Research in Marketing 34 (1), 22-45, 2017. https://doi.org/10.1016/j.ijresmar.2016.11.006

54. C. Wu,H-L. Chen, "Counting your customers: Compounding customer's in-store decisions, interpurchase time and repurchasing

behavior" European Journal of Operational Research, 127(1), 109-119. 2000. https://doi.org/10.1016/S0377-2217(99)00326-4

55. C.M. Chiu, T.G.W. Eric, F. Yu-Hui, H. Hsin-Yi, "Understanding customers' repeat purchase intentions in $\mathrm{B} 2 \mathrm{C}$ e-commerce: the roles of utilitarian value, hedonic value and perceived risk." Information Systems Journal 24,(1) 85-114. 2014 https://doi.org/10.1111/j.1365-2575.2012.00407.x

56. C,S. Patro,. "Predicting Consumers' Acceptance of Online Shopping on the Internet: An Empirical Study." International Journal of Cyber Behavior, Psychology and Learning (IJCBPL) 8 (1), 33-60, 2018. https://doi.org/10.4018/JCBPL.2018010103.

57. I. Ajzen, "The theory of planned behavior." Organizational behavior and human decision processes, 50(2), 179-211, 1991 https://doi.org/10.1016/0749-5978(91)90020-T

58. N. Hajli, X. Lin, 'Consumer adoption of social commerce. In International Conference on HCI in Business, 279-287, Springer, Cham, 2015. https://doi.org/10.1007/978-3-319-20895-4 26.

59. P.A. Pavlou, "Consumer acceptance of electronic commerce: Integrating trust and risk with the technology acceptance model". International journal of electronic commerce, 7(3), 101-134, 2003. https://doi.org/10.1080/10864415.2003.11044275

60. G.A. Churchill, T.J. Brown. Basic marketing research, (5th ed), Ohio: South-Western. 2004

61. D.R. Cooper, \& P.S. Schindler, Marketing Research. New York: McGraw-Hill/Irwin.2006

62. A Strong Reliable Internet Connection A Strong Reliable Internet Connectionhttps://www.morganstanley.com/ideas/india-millennials-makeo ver-disruption-growth

63. Department of Higher Education, Chandigarh, http://rusa.nic.in/download/365/shep/5355/chandigarh-shep.pdf

64. D.W. Gerbing, J.C. Anderson, "An updated paradigm for scale development incorporating unidimensionality and its assessment" Journal of marketing research, 25(2), 186-192， 1988 https://doi.org/10.1177/002224378802500207

65. J. Kim, C.W. Mueller, Factor Analysis: Statistical Methods and Practical Issues, Sage Publications, Beverly Hills, Cat 1982.

66. J.F. Hair, R.E.Anderson, R.L. Tatham, \& W.C.Black, " Multivariate data analysis. Englewood Cliff. New Jersey, USA, 5(3), 207-2019, 1998.

67. A.Aron, \& E. Aron,"Statistics for psychology" (2 ed.). Upper Saddle River, NJ: Prentice Hall. 1999.

68. P.R. Hinton, I. McMurray, \& C. Brownlow, SPSS explain, New York: Routledge, 2004

69. I.Goyette, R. Line ,B. Jasmin, M,François, "e-WOM Scale: word-of-mouth measurement scale for e-services context" Canadian Journal of Administrative Sciences/Revue Canadienne des Sciences de l'Administration, 27(1), 5-23,2010.https://doi.org/10.1002/cjas.129

70. E. Brunelle, L. Josée, "Testing media richness theory to explain consumers' intentions of buying online." In Proceedings of the 10th international conference on Electronic commerce, 31. ACM, 2008. https://doi.org/10.1145/1409540.1409582

71. L. Gao, A.W. Kerem , B. Xuesong, "Understanding consumers' continuance intention towards mobile purchase: A theoretical framework and empirical study-A case of China" Computers in Human Behavior 53,

2015.https://doi.org/10.1016/j.chb.2015.07.014

72. G.R.Dowling, "Perceived risk: The concept and its measurement. Psychology \& Marketing" 3 (3), 193-210, 1986. https://doi.org/ 10.1002/mar.4220030307

73. P.L.Hsieh, "Perceived opportunism (PO) in e-return service encounters" Managing Service Quality: An International Journal 23, ( 2) 96-110, 2013.https://doi.org/10.1108/09604521311303390

74. B,M. Byrne, Structural equation modeling with AMOS: Basic concepts, applications, and programming. Routledge, 2016. https://doi.org/10.4324/9781315757421

75. T.H. Thurau, K. P. Gwinner, G.Walsh,, \& D.D. Gremler, "Electronic word-of-mouth via consumer-opinion platforms: What motivates consumers to articulate themselves on the internet? Journal of Interactive Marketing, $\quad 18(1), \quad 38 \mathrm{e} 52$ 2004.https://doi.org/10.1002/dir.10073

76. N. Huete-Alcocer, "A literature review of word of mouth and electronic word of mouth: Implications for consumer behaviour" Frontiers in psychology, 8, 1256, 2017. https://doi.org/10.3389/fpsyg.2017.01256 
77. S.K. Ariffin, T. Mohan, Y.N. Goh, “Influence of consumers' perceived risk on consumers' online purchase intention. Journal of Research in Interactive Marketing, 12(3), 309-327, 2018 https://doi.org/10.1108/JRIM-11-2017-0100

78. S. Teng, K. Wei Khong, W, Wei Goh, \& A. Yee Loong Chong, "Examining the antecedents of persuasive eWOM messages in social media. Online Information Review, 38(6), 746-768, 2014. https://doi.org/10.1108/OIR-04-2014-0089

79. M. D., Clemes, C. Gan, \& J. Zhang, "An empirical analysis of online shopping adoption in Beijing, China" Journal of Retailing and Consumer Services, 21(3), 364-375, 2014 https://doi.org/10.1016/j.jretconser.2013.08.003S.

80. J.M.T.Heinze, P. Fischer, "Ladders to m-commerce resistance: A qualitative means-end approach." Computers in Human Behavior, 73,362-374, 2017. https://doi.org/10.1016/j.chb.2017.03.059

81. A. Bilgihan, J. Kandampully, T.Zhang. "Towards a unified customer experience in online shopping environments: Antecedents and outcomes." International Journal of Quality and Service Sciences, 8(1), 102-119. 2016. https://doi.org/10.1108/IJQSS-07-2015-0054

82. E.K.Clemons, J. Wilson, C. Matt, T. Hess, F.Ren, F.Jin, N.S. Koh. "Global differences in online shopping behavior: Understanding factors leading to trust." Journal of Management Information Systems $33 \quad$ (4), 1117-1148, 2016 https://doi.org/10.1080/07421222.2016.1267531

83. A. Bilgihan, "Gen Y customer loyalty in online shopping: An integrated model of trust, user experience and branding." Computers in Human Behavior, 61, 103-113, 2016 https://doi.org/10.1016/j.chb.2016.03.014

84. A.H. Eagly, S. Chaiken, "The impact of attitude on behavior in The Psychology of Attitudes", Orlando, FL: Harcourt Brace \& Co, 1993.

85. S.Shim \& M.F. Drake, "Consumer intention to utilize electronic shopping", Journal of Direct Marketing, 4 (2) , 22-33, 1990. https://doi.org/10.1002/dir.4000040305

86. K. C Ling, L. T. Chai, \& T. H. Piew, "The effects of shopping orientations, online trust and prior online purchase experience toward customers' online purchase intention" International Business Research, 3(3), 63, 2010. https://doi.org/10.1002/dir.4000040305 